\title{
Peran Sistem Skoring Hematologi dalam Diagnosis Awal Sepsis Neonatorum Awitan Dini
}

\author{
Ranti Adriani,* Eny Yantri,* Rinang Mariko* \\ *Departemen Ilmu Kesehatan Anak Fakultas kedokteran Universitas Andalas/RSUP dr. M. Djamil, Padang
}

\begin{abstract}
Latar belakang. Sepsis neonatorum awitan dini (SNAD) merupakan penyebab utama kesakitan dan kematian pada neonatus. Adanya gejala klinis yang tidak spesifik dan keterbatasan sarana pemeriksaan penunjang masih merupakan masalah dalam diagnosis sepsis. Sistem skoring hematologi (SSH) dapat digunakan sebagai metode deteksi awal SNAD.

Tujuan. Mengetahui apakah sistem skoring hematologi (SSH) dapat digunakan dalam diagnosis awal SNAD.

Metode. Penelitian ini merupakan penelitian cross sectional dan uji diagnostik pada bayi dengan risiko dan diduga sepsis neonatorum awitan dini yang dirawat di NICU/Perinatologi RSUP Dr. M Djamil Padang dari bulan Oktober 2016 hingga Juni 2017. Diagnosis sepsis ditegakkan berdasarkan pemeriksaan klinis dan biakan darah. Sistem skoring hematologi terdiri delapan parameter hematologis. Hasil. Subjek penelitian 78 pasien, terdiri dari tidak sepsis 30 orang (38\%) sepsis klinis 28 orang (36\%) dan terbukti sepsis 20 orang (26\%). Nilai SSH tidak sepsis lebih rendah dari kelompok sepsis klinis dan terbukti sepsis. Tidak terdapat perbedaan yang bermakna nilai SSH kelompok terbukti sepsis dan sepsis klinis. Nilai SSH $\geq 2$ memiliki nilai sensitifitas $100 \%$, spesifitas $25,8 \%$ dalam mendiagnosis sepsis (bakteremia) pada bayi dengan dugaan SNAD.

Kesimpulan. Sistem skoring hematologi ini dapat digunakan sebagai metode deteksi awal sepsis neonatorum awitan dini, terutama di rumah sakit dengan sarana pemeriksaan penunjang terbatas. Sari Pediatri 2018;20(1):17-23
\end{abstract}

Kata kunci: sepsis neonatorum, sistem skoring hematologi, diagnosis awal

\section{The Role of A Hematology Scoring System in Early Onset Neonatal Sepsis Diagnosis}

\author{
Ranti Adriani,* Eny Yantri,* Rinang Mariko*
}

Background. Early onset neonatal sepsis (EONS) is a major cause of neonatal morbidity and mortality. Non-specific clinical symptoms and limited investigation facilities are some of the problems in the management of sepsis. The hematological scoring system can be used as an early detection tool for EONS.

Objective. The purpose of the study is to evaluate whether a hematological scoring system can be useful in early diagnosis of EONS Method. This study is a cross-sectional study and diagnostic test in infants with risk and suspected EONS treated at NICU/Neonatology Department Perinatology Dr. M. Djamil Hospital in Padang, from October 2016 through June 2017. The diagnosis of sepsis is based on clinical examination and blood culture results.

Results. Subjects were 78 patients, consisting of 30 (38\%) as nonsepsis, 28 (36\%) as clinical sepsis and 20 (26\%)were proven to have sepsis. Hematologic scores in non-sepsis were lower compared to the clinical sepsis and proven sepsis groups. There were no significant differences in hematologic score of proven sepsis and clinical sepsis. The score of $\geq 2$ on hematologic scoring system had $100 \%$ sensitivity, $25,8 \%$ specificity for diagnosis of bacteremia in infants at risk and suspected EONS.

Conclusion. This hematological scoring system can be utilized as an early detection method of early-onset neonatal sepsis, especially in hospitals with limited investigation tools. Sari Pediatri 2018;20(1):17-23

Keywords: neonatal sepsis, haematological scoring system, early diagnosis

Alamat korespondensi: Ranti Adriani. Departemen Ilmu Kesehatan Anak FK-UNAND/RSUP dr.M.Djamil Jl. Perintis Kemerdekaan. Padang, Sumatera Barat. Email: achi_adriani@yahoo.com 
A ngka kejadian penyakit infeksi dan sepsis neonatorum di negara berkembang berkisar antara 7,1-38 per 1000 kelahiran hidup, sedangkan di negara maju berkisar $1-5$ per 1000 kelahiran hidup. ${ }^{1}$

Di Indonesia, berdasarkan hasil Survei Demografi dan Kesehatan Indonesia (SDKI) tahun 2012, angka Kematian Neonatus (AKN) pada tahun 2012 sebesar 19 per 1000 kelahiran hidup. Sepsis menjadi penyebab terbesar, $20,6 \%$ untuk umur $0-28$ hari dan $12 \%$ untuk umur 0-6 hari. $^{2}$

Sepsis neonatorum awitan dini merupakan infeksi perinatal yang terjadi segera dalam periode postnatal (kurang dari 72 jam) dan biasanya diperoleh pada saat proses kelahiran atau in utero. Sepsis awitan dini memiliki case fatality rate lebih tinggi dibanding sepsis awitan lambat. ${ }^{3-5}$

Keterlambatan diagnosis sepsis neonatorum merupakan faktor perinatal yang belum dapat ditangani secara optimal karena tanda-tanda sepsis klasik pada bayi baru lahir sulit ditemukan. Selain itu, banyak bayi baru lahir yang terinfeksi dari ibu tapi tidak memberikan gejala segera setelah lahir. Namun sebaliknya, tidak semua bayi dengan ibu yang memiliki faktor risiko mengalami sepsis neonatorum.

Biakan darah adalah pemeriksaan baku untuk sepsis neonatorum. Namun, deteksi adanya bakteriemia masih sulit karena waktu analisis mikrobiologi cukup lama (4872 jam) dan tidak semua bakteri dapat diidentifikasi, di samping fasilitas kesehatan tidak menunjang. ${ }^{8-9}$

Pemeriksaan rutin laboratorium hematologi bisa dilakukan hampir di setiap rumah sakit, sederhana, mudah dilakukan, biaya relatif murah, dan tidak membutuhkan waktu lama. Pemeriksaan hematologi dan sediaan hapus darah tepi dapat menggambarkan secara mikroskopik morfologi sel darah yang dapat digunakan untuk evaluasi diagnostik infeksi sistemik pada neonatus. ${ }^{8}$

Parameter hematologi dan biologi dikembangkan setiap tahunnya dari berbagai penelitian sepsis neonatorum pada bayi baru lahir, seperti CRP, prokalsitonin, neopterin dan sistem skoring hematolog. $\mathrm{i}^{10-13}$ Parameter hematologi yang digunakan, seperti gambaran eritrosit, retikulosit, jumlah leukosit, neutrofil absolut, rasio neutrofil imatur dan matur, trombosit, laju endap darah, granular toksik, vakuolisasi sitoplasma pada hapusan darah tepi, jumlah sel eosinofil dan eritrosit berinti. ${ }^{14-16}$ Setiap parameter hematologi memiliki nilai sensitifitas, spesifitas, nilai prediktif positif dan negatif yang teruji. Kombinasi ini diharapkan dapat memberi arti pemeriksaan yang lebih reliabel dan tepat dalam membantu diagnosis dini sepsis neonatorum.

Berdasarkan hal tersebut di atas, maka peneliti tertarik melakukan suatu penelitian menggunakan pemeriksaan sistem skoring hematologi dengan pembanding biakan darah dan kriteria klinis sepsis untuk deteksi awal sepsis neonatorum awitan dini.

\section{Metode}

Penelitian dilakukan di Instalasi Rawat Inap Anak dan Kebidanan RS M Djamil Padang. Subjek penelitian ini adalah semua pasien bayi usia kurang dari 72 jam dengan dugaan SNAD yang memenuhi kriteria inklusi dan ekslusi.

Kriteria inklusi adalah bayi dengan faktor risiko infeksi (bayi berat badan lahir rendah, bayi prematur, riwayat ibu premature ruptur of membranes $(\mathrm{PROM})>18 \mathrm{jam}$, ibu demam $\geq 37,8^{\circ} \mathrm{C}$, riwayat ibu chorioamnionitis) atau bayi tanpa faktor risiko infeksi dengan dugaan sepsis sesuai kriteria IDAI. Kriteria eksklusi adalah bayi dengan kelainan kongenital mayor, inborn error metabolism, usia gestasi kurang dari 34 minggu, bayi dengan hemolitic jaundice.

Setiap subjek penelitian dilakukan pemantauan klinis, dilakukan pemeriksaan hematologi dan biakan darah. Sepsis ditegakkan sesuai kriteria klinis dan pemeriksaan biakan darah. Setelah dilakukan pemantauan dan pemeriksaan subjek penelitian dikelompokkan sebagai tidak sepsis, sepsis klinis dan terbukti sepsis (bakteremia).

Sistem skoring hematologi terdiri dari delapan parameter hematologis, merupakan modifikasi SSH Rodwell. Parameter hematologi yang ditemukan, masing-masing diberi skor satu, apabila semua parameter ditemukan memiliki total skor 8. Parameter Sistem skoring hematologis yang digunakan tertera pada Tabel 1 .

Desain penelitian adalah uji diagnostik dengan rancangan penelitian potong lintang. Analisis statistik diawali dengan uji normalitas data. Uji Kruskal-Wallis dilakukan karena distribusi data tidak normal, untuk melihat perbedaan nilai sistem skoring hematologis berdasarkan kelompok sepsis. Data diolah dengan program SPSS versi 16.0 dengan kemaknaan $\mathrm{p}<0,05$. Penelitian sudah mendapat izin dari Komite Etik Penelitian Fakultas Kedokteran Universitas Andalas. 
Tabel 1. Sistem skoring hematologis

\begin{tabular}{lc}
\hline Parameter hematologi & Skor \\
\hline I/T ratio $>0,12$ & 1 \\
Jumlah absolut PMN $<7.800$ atau $>14.500 / \mathrm{mm} 3$ & 1 \\
I/M ratio $>0,3)$ & 1 \\
Jumlah absolut granulosit imatur meningkat $>$ & 1 \\
$600 / \mathrm{mm}^{3}$ & \\
Jumlah leukosit $<5000 / \mathrm{mm} 3$ atau $>25.000 / \mathrm{mm}^{3}$ & 1 \\
Jumlah trombosit $<150.000 / \mathrm{mm} 3$ & 1 \\
Nucleated red blood cell counts $>10 / 100$ leukosit & 1 \\
Persentase eosinofil $<0,78 \%$ & 1 \\
\hline Total & 8 \\
\hline I/T ratio: Immature to total neutrophil ratio, I/M ratio- Immature to \\
mature neutrophil ratio. PMN: polimorfonuklear
\end{tabular}

\section{Hasil}

Penelitian telah dilakukan terhadap bayi dengan risiko dan dugaan sepsis neonatorum selama Oktober 2016 sampai Juni 2017. Selama periode penelitian didapatkan 78 pasien, 30 (38\%) kelompok tidak sepsis dan 48 kelompok sepsis, yang terdiri dari sepsis klinis $28(36 \%)$ dan terbukti sepsis 20 (26\%). Tigabelas (17\%) meninggal sampai pada akhir rawat. Data demografi dan karakteristik subjek penelitian tertera pada Tabel 2.

Distribusi bakteri penyebab sepsis neonatorum pada kelompok terbukti sepsis tertera pada Tabel 3. Tabel. 4 menunjukkan hasil analisis uji Kruskal-

Tabel 2. Karakteristik subjek penelitian

\begin{tabular}{|c|c|c|c|}
\hline Karakteristik & $\begin{array}{l}\text { Tidak sepsis } \\
\quad(\mathrm{n}=30)\end{array}$ & $\begin{array}{l}\text { Sepsis klinis dan } \\
\text { terbukti sepsis } \\
\quad(\mathrm{n}=48)\end{array}$ & $\mathrm{p}$ \\
\hline \multicolumn{4}{|l|}{ Jenis kelamin } \\
\hline Laki-laki & $17(40)$ & $25(60)$ & \multirow[t]{2}{*}{$0,693^{*}$} \\
\hline Perempuan & $13(36)$ & $23(64)$ & \\
\hline \multicolumn{4}{|l|}{ Berat badan lahir } \\
\hline$<2500$ & $9 \quad(28)$ & $23(72)$ & \multirow[t]{2}{*}{$0,118^{*}$} \\
\hline$\geq 2500$ & $21(46)$ & $25(54)$ & \\
\hline \multicolumn{4}{|c|}{ Usia kehamilan (minggu) } \\
\hline$<37$ & $13(31)$ & $29(69)$ & \multirow[t]{2}{*}{$0,141^{*}$} \\
\hline$>37$ & $17(47)$ & $19(53)$ & \\
\hline \multicolumn{4}{|l|}{ Cara persalinan } \\
\hline Spontan & $6 \quad(29)$ & $15(71)$ & \multirow[t]{2}{*}{$0,276^{*}$} \\
\hline Sectio cesarea & $24(42)$ & $33(58)$ & \\
\hline \multicolumn{4}{|c|}{ Riwayat demam ibu } \\
\hline Demam & $8(33)$ & $16(67)$ & \multirow[t]{2}{*}{$0,535^{*}$} \\
\hline Tidak demam & $22(41)$ & $32(59)$ & \\
\hline \multicolumn{4}{|c|}{ Riwayat KPD >18 jam } \\
\hline Ada & $3(38)$ & $5(62)$ & \multirow[t]{2}{*}{$0,634^{* *}$} \\
\hline Tidak ada & $27(39)$ & $43(61)$ & \\
\hline \multicolumn{4}{|c|}{ Riwayat ketuban hijau berbau } \\
\hline Ada & $13(45)$ & $16(55)$ & \multirow[t]{2}{*}{$0,374^{*}$} \\
\hline Tidak ada & $17(35)$ & $32(65)$ & \\
\hline \multicolumn{4}{|c|}{ Riwayat ibu leukositosis } \\
\hline Ada & $15(44)$ & $19(56)$ & \multirow{2}{*}{$0,367^{*}$} \\
\hline Tidak & $15(34)$ & $29(66)$ & \\
\hline \multicolumn{4}{|c|}{ APGAR score menit ke $5<7$} \\
\hline Ada & $3 \quad(18)$ & $14(82)$ & \multirow[t]{2}{*}{$0,046^{*}$} \\
\hline Tidak & $27 \quad(44)$ & $34(56)$ & \\
\hline
\end{tabular}

*: uji chi-square ${ }^{* *}$ : uji fisher 
Ranti Adriani dkk: Peran sistem skoring hematologi dalam diagnosis awal sepsis neonatorum awitan dini

Tabel 3. Bakteri penyebab sepsis neonatorum

\begin{tabular}{lcc}
\hline Jenis bakteri & Jumlah (n) & $\%$ \\
\hline Klebsiella spp & 12 & 60 \\
Staphylococcus aureus & 4 & 20 \\
Pseudomonas aeruginosa & 3 & 15 \\
Staphylococcus epidemidis & 1 & 5 \\
\hline Total & 20 & 100 \\
\hline
\end{tabular}

Tabel 4. Perbedaan nilai sistem skoring hematologi pada masing-masing kelompok

\begin{tabular}{lccc}
\hline $\begin{array}{l}\text { Sepsis } \\
\text { neonatorum } \\
\text { awitan dini }\end{array}$ & N (\%) & $\begin{array}{c}\text { Nilai sistem } \\
\text { skoring } \\
\text { hematologi } \\
\text { (median) (min- } \\
\text { max) }\end{array}$ & $\mathrm{p}$ \\
\hline Tidak sepsis & 30 & $1,5(0-4)$ & $<0,0001^{*}$ \\
Sepsis klinis & 28 & $3,5(1-6)$ & \\
Terbukti sepsis & 20 & $4(2-7)$ & \\
\hline
\end{tabular}

Tabel 5. Sistem skoring hematologi berdasarkan hasil pemeriksaan biakan darah

\begin{tabular}{lcccc}
\hline $\begin{array}{l}\text { Nilai } \\
\text { SSH }\end{array}$ & $\begin{array}{c}\text { Sensitivitas } \\
(\%)\end{array}$ & $\begin{array}{c}\text { Spesifisitas } \\
(\%)\end{array}$ & $\begin{array}{c}\text { NPP } \\
(\%)\end{array}$ & $\begin{array}{c}\text { NPN } \\
(\%)\end{array}$ \\
\hline$\geq 1$ & 100 & 10 & 27,7 & 100 \\
$\geq 2$ & 100 & 25,8 & 30,7 & 100 \\
$\geq 3$ & 85 & 60,3 & 42,5 & 92,1 \\
$\geq 4$ & 60 & 74,1 & 44,4 & 84,3 \\
$\geq 5$ & 35 & 86,2 & 46,6 & 79,3 \\
$\geq 6$ & 10 & 94,8 & 40 & 75,3 \\
$\geq 7$ & 5 & 100 & 100 & 75,3 \\
\hline
\end{tabular}

NPP : nilai prediksi positif, NPN : Nilai prediksi negatif

Wallis perbedaan nilai sistem skoring hematologi pada masing-masing kelompok. Nilai median skoring hematologi tidak sepsis lebih rendah dari kelompok sepsis klinis dan terbukti sepsis.

Uji post Hoc Mann Whitney, terdapat perbedaan yang bermakna nilai SSH subjek penelitian kelompok tidak sepsis dengan kelompok terbukti sepsis dan sepsis klinis. Tetapi tidak terdapat perbedaan yang bermakna antara sepsis klinis dengan terbukti sepsis.

Titik potong nilai SSH untuk menentukan diagnosis sepsis berdasarkan biakan darah (bakteremia ) dinilai dengan menggunakan kurva ROC, diperoleh nilai $\geq 3$ mempunyai nilai sensitivitas dan spesifisitas yang paling optimal, dengan luas AUC sebesar 75,9\% (IK95\% 65,1-86). Analisis uji diagnostik sistem skoring hematologi berdasarkan hasil pemeriksaan biakan darah tertera pada Tabel 5.

\section{Pembahasan}

Secara klinis dengan atau tanpa bakteremia, kejadian sepsis neonatorum terdapat pada $61 \%$ dari 78 subjek selama periode penelitian. Angka kematian terjadi pada $17 \%$ bayi yang diduga atau memiliki risiko tinggi sepsis neonatorum awitan dini. Persentase kematian pada penelitian ini tidak jauh berbeda dengan penelitian di RS Adam Malik Medan pada tahun 20082010 yang melaporkan tingkat mortalitas dari sepsis neonatal adalah $20 \% .{ }^{17}$

Tidak terdapat perbedaan kelompok sepsis neonatorum berdasarkan klinis atau bakteremia dengan tidak sepsis terhadap jenis kelamin, berat badan lahir, usia kehamilan, jenis persalinan, riwayat ibu demam, ibu leukositosis, ketuban hijau berbau dan ketuban pecah dini. Hubungan yang bermakna terdapat pada Apgar score menit ke-5 $>7$. Hal tersebut menunjukkan subjek penelitian lebih bersifat homogen dan dinilai dapat mengurangi bias terhadap nilai parameter tunggal hematologi dan total skor hematologi yang didapatkan.

Sistem skoring hematologi meliputi kombinasi delapan parameter hematologi tunggal. Pemeriksaan dari apusan darah tepi,yang meliputi $I T$ ratio, IM ratio, absolut PMN, jumlah leukosit,absolut granulosit imatur, jumlah trombosit, eritrosit berinti, dan eosinopenia. Nilai batas abnormalitas pada setiap parameter berdasarkan sistem skoring hematologi Rodwell dengan dua parameter hematologi tambahan yang sudah dilakukan penelitian sebelumnya. ${ }^{14,16-19}$

Nilai sistem skoring hematologi yang lebih tinggi didapat pada kelompok sepsis klinis dan terbukti sepsis dibanding dengan kelompok tidak sepsis. Semakin tinggi nilai sistem skoring, semakin menunjukkan kemungkinan besar sepsis dan sebaliknya. Namun, simplifikasi dan standarisasi interprestasi uji secara global masih dibutuhkan. ${ }^{18-20}$ Hasil pemeriksaan sistem skoring hematologi mendapatkan perbedaan nilai sistem skoring antara kelompok tidak sepsis dengan sepsis klinis dan terbukti sepsis. Sementara terdapat juga perbedaan antara nilai sistem skoring hematologi kelompok sepsis klinis dan terbukti sepsis. Hal tersebut disebabkan kelompok sepsis dan terbukti sepsis sama karena terdapat kriteria klinis yang sesuai dengan sepsis selama pengamatan. Namun, dibedakan dengan 
ada atau tidaknya bakteremia yang diperiksa dengan pemeriksaan biakan darah. Kejadian bakteremia atau tanpa bakteremia berdasarkan hasil biakan darah dari laboratorium dan tidak menutup kemungkinan adanya hasil positif palsu maupun negatif palsu sehingga kemungkinan sepsis neonatorum belum benar-benar dapat disingkirkan.

Hasil biakan positif terdapat pada $42 \%$ subjek penelitian yang memenuhi kriteria klinis sepsis, 25 $\%$ dari keseluruhan subjek penelitian dengan risiko sepsis neonatorum awitan dini. Hasil tersebut tidak jauh berbeda dari penelitian Panwar $\mathrm{dkk}^{21}$ yang melaporkan biakan darah positif $48 \%$ dari keseluruhan neonatus dengan klinis sepsis. Namun, lebih tinggi dari penelitian Lestiadi $\mathrm{dkk}^{22}$ yang melaporkan 14\% dari keseluruhan sampel dengan klinis sepsis dengan biakan darah positif.

Biakan darah merupakan pemeriksaan baku emas untuk diagnostik definitif sepsis neonatorum dengan mengisolasi patogen penyebab dari darah. Akurasi biakan darah sangat dipengaruhi oleh banyak faktor, seperti kontaminasi selama pengumpulan sampel, pengumpulan sampel setelah pemberian antibiotik dimulai, volume sampel darah yang kurang, dan waktu pemeriksaan setelah pengumpulan sampel darah dan terdapat bakteremia dengan jumlah koloni kuman yang rendah. Akurasi pemeriksaan biakan darah bervariasi antara $8 \%-73 \%$ dari beberapa penelitian. ${ }^{24}$

Sebagian besar hasil pemeriksaan biakan darah yang didapatkan adalah isolasi kuman Klebsiella spp, diikuti oleh Pseudomonas aurigenosa, Staphylococcus aerus, dan Staphylococcus epidemididis. Hal tersebut diduga disebabkan adanya kesamaan paparan kolonisasi kuman dari ibu saat dalam kandungan maupun saat persalinan. Penelitian Panwar $\mathrm{dkk}^{21}$ mendapatkan isolasi kuman dari urin dan cairan vagina ibu. Isolasi kuman hampir sama dengan yang didapat pada bayi, dengan jenis kuman terbanyak adalah E.Coli, Klebsiella, Staphylococcus aereus, Staphylococcus, coagulase negatif Pseudomonas dan Streptococcus. Selain itu, sesuai dengan epidemiologi, kuman penyebab tersering yang ditemukan pada kasus sepsis neonatorum awitan dini di negara maju adalah Streptococcus Grup $B$ (SGB), E. coli, Haemophilus influenzae, dan Listeria monocytogenes. Sementara di negara berkembang termasuk Indonesia, mikroorganisme penyebabnya adalah batang Gram negatif (E. coli, Klebsiella, dan Pseudomonas aeruginosa). $4,5,24$

Sistem skoring hematologi pada penelitian ini, terdiri dari delapan parameter. Nilai sistem skoring $\geq 3$ didapatkan sebagai titik potong dengan menggunakan grafik ROC yang dianalisis dengan SPSS versi 16.0. Nilai $\geq 3$ memiliki nilai sensitivitas $85 \%$ dan spesifitas $59 \%$, nilai prediksi positif (NPP) $42,5 \%$ dan nilai prediksi negatif(NPN) $91,9 \%$. Sementara nilai sistem skoring $\geq 2$ sebagai titik potong memiliki memiliki nilai sensitivitas $100 \%$ dan spesifitas $25,8 \%$, nilai prediksi positif(NPP) 30,7 \% dan nilai prediksi negatif (NPN) 100\%. Namun, untuk tujuan deteksi awal pada populasi yang berisiko sepsis neonatorum lebih diutamakan suatu pemeriksaan dengan sensitivitas yang lebih tinggi.

Apabila skor $\geq 2$, sistem skoring hematologis dapat mendeteksi 100\% bakteremia, Sebaliknya, skor <2 dapat mendeteksi 25,8\% non bakteremia. Apabila skor $\geq 3$, sistem skoring hematologis dapat mendeteksi $85 \%$ bakteremia. Sebaliknya, skor $<3$ dapat mendeteksi $59 \%$ non bakteremia. Dengan demikian, untuk tujuan deteksi awal, skor $\geq 2$ lebih baik digunakan.

Khair $\mathrm{dkk}^{25}$ melakukan penelitian tentang sistem skoring hematologi dalam deteksi awal sepsis neonatorum. Khair melaporkan 6 parameter hematologi dalam sistem skoring hematologi yang digunakan dalam penelitiannya. Batas skor 4 memiliki sensitivitas $100 \%$ dan spesifisitas $60 \%$, dengan spesifisitas lebih tinggi dari nilai batas skor 3. Nilai sistem skoring hematologi 3 memiliki sensitivitas $100 \%$ dan spesifisitas hanya 26\%. Uji validitas sistem skoring hematologi Rodwell, ${ }^{19}$ yang terdiri dari tujuh parameter hematologi, dilakukan oleh Iskandar $\mathrm{dkk}^{18}$ melaporkan sensitivitas $100 \%$ dan spesifisitas $66 \%$, dengan batas bukan sepsis $\leq 2$, skor 3-4 diduga sepsis dan $\geq 5$ sepsis.

Sistem skoring hematologi berdasarkan uji diagnostik, memiliki tingkat sensitivitas yang baik, tetapi tingkat spesifisitas yang lemah dalam mendiagnosis sepsis berdasarkan biakan darah (bakteremia). Nilai spesifisitas yang lemah dan nilai prediksi positif yang rendah pada uji ini disebabkan karena kelompok sepsis secara klinis. Namun, tidak terbukti dari pemeriksaan biakan darah dengan jumlah subjek penelitian yang cukup banyak. Adanya biakan darah negatif pada kelompok ini belum bisa menyingkirkan sepenuhnya kemungkinan diagnosis sepsis karena biakan darah positif pada pasien sepsis neonatorum hanya berkisar $10 \%-60 \%$ saja. $^{26}$

Keterbatasan penelitian ini adalah penentuan nilai batas skor hematologi dengan melakukan uji diagnostik 
hanya dapat membedakan kelompok sepsis berdasarkan bakteremia dan non- bakteremia. Sementara kelompok sepsis klinis tidak didapatkan bakteremia dan dinilai merupakan kelompok berisiko mortalitas tinggi yang harus ditatalaksana dini. Namun, hasil penelitian ini menyatakan tidak ada perbedaan nilai sistem skoring hematologi kelompok sepsis klinis dengan terbukti sepsis (bakteremia) berdasarkan uji post hoc. Dengan demikian, nilai batas skor hematologi yang digunakan kemungkinan bisa dianggap sama dalam memprediksi sepsis baik dengan maupun tanpa bakteremia.

Kelemahan penelitian ini adalah pemeriksaan biakan darah sebagai baku emas diagnosis sepsis yang tidak sempurna sehingga standar uji diagnostik tidak dapat dilakukan . Biakan darah negatif tidak dapat menyingkirkan diagnosis sepsis neonatorum apabila klinis dan pemeriksaan lainnya menunjang, begitupun sebaliknya.

Salah satu metode pemeriksaan kultur yang cenderung lebih bisa mendeteksi kuman dalam konsentrasi yang rendah hingga 1-2 CFU/ml adalah BACTEC atau BACT/ALERT culture system. Namun, metode tersebut belum tersedia saat penelitian dilakukan dan dana peneliti yang terbatas untuk melakukan pemeriksaan di laboratorium swasta pada semua bayi dengan risiko dan dugaan sepsis neonatorum awitan dini.

\section{Kesimpulan}

Sistem skoring hematologi ini dapat digunakan sebagai pedoman oleh klinisi dalam tatalaksana awal pada bayi dengan risiko dan diduga sepsis neonatorum awitan dini terutama di Rumah sakit dengan fasilitas terbatas.

\section{Daftar pustaka}

1. Aminullah A. Masalah terkini sepsis neonatorum. Dalam: Hegar B, Trihono P, Ifran EB, penyuting. Update in neonatal infection. ,Jakarta: Departemen Ilmu kesehatan Anak FKUI RSCM;2005.h.1-15.

2. Departemen Kesehatan Republik Indonesia. Survei Demografi dan Kesehatan Indonesia. Depkes RI; 2011.

3. Centers for Disease Control and Prevention. Prevention of perinatal group B streptococcal disease-revised guidelines from CDC. MMWR Recomm Rep 2010;59:1-36.
4. Gomella TL, Cunningham MD, Eyal FG, Zenk KE, penyunting. Infectious diseases. Dalam: Neonatology: Management, Procedures, On-Call Problems, Diseases, and Drugs. Edisi ke-5. McGraw-Hill Companies; 2009.h.434-81.

5. Gonzalez A, Spearman, Stoll B. Neonatal infectious disease: Evaluation of neonatal sepsis. Pediatr Clin N Am 2013 60:36789.

6. Polin RA and the Commitee on Fetus and Newborn. Management of Nenonates with Suspected or Proven EarlyOnset Bacterial Sepsis. Pediatrics 2012;129.1006-15.

7. Brady MT and. Polin RA. Prevention and Management of Infants With Suspected or Proven Neonatal Sepsis. Pediatrics 2013;132:166.

8. Shirazi H, Riaz S, Tahir R. Role of the hematological profile in early diagnosis of neonatal sepsis. Ann Pak Inst Med Sci 2010;6:152-6.

9. Narasimha A and Kumar ML. Significance of hematological scoring system (HSS) in early diagnosis of neonatal sepsis. Indian J Hematol Blood Transfus 2011;27:14.

10. Hakeem, Mohsen AHA, Kamel BA. Role of procalcitonin in the diagnosis of neonatal sepsis. Int J Adv Res Biol Sci 2015;2:48-54.

11. Swarnkar K, Vagha J. Sepsis Biomarkers In Early Onset Neonatal Infections: A Review. Int J Infect Dis 2013;11:1-9.

12. Dhanamjayaraoteeda, Rajendra. A Study of peripheral smears in neonates. IOSR. J Dental and Medical Scie 2015;14;55-64.

13. Darnifayanti, Tjipta GD, Rusdidjas, Lubis BM. Immatureto-total neutrophil ratio as an early diagnostic tool of sepsis. Paediatr Indones: 2015;55:153-7.

14. Yefta EK, Yuniati T, Rahayuningsih SE. Validitas eosinopenia sebagai penanda diagnosis pada sepsis neonatal bakterialis. Maj Kedokt lndon 2009;59:602-5s.

15. Pardede DKB, Siahaan D. Eosinopenia sebagai penanda diagnosis sepsis. CDK-221 2014;41;741-4.

16. Abhishek MG, Sanjay. Diagnostic efficacy of nucleated red blood cell count in the early diagnosis of neonatal sepsis. Indian J Pathol Oncol 2015;2;182-5.

17. Sianturi P, Hasibuan RS, Lubis BM, Azlin E, Tjipta GD. Profil sepsis neonatus di unit perawatan neonatus RSUP H. Adam Malik Medan tahun 2008-2010. Sari Pediatri 2012;14:6772.

18. Iskandar TR, Dalimonthoe NZ, Yuniati T, Turbawati D. Validitas SSH Rodwell untuk deteksi dini sepsis neonatorum awitan dini. Sari Pediatri 2015;16:330-6.

19. Rodwell RL, Lerlie Al, Tudehope DI. Early diagnosis of neonatal sepsis using a Hematologic scoring system. J Pediatric. 1988;112:761-7.

20. Khair R, Sultana T, Roy CK, Rahman MD, Shahidullah $\mathrm{M}$, Ahmed N. Role of hematologic scoring system in early 
diagnosis of neonatal septicemia. BSMMU J 2010;3:62-7.

21. Panwar C, Kaushik SL, Kaushik R, Sood A. Corellation of neonatal and maternal clinico-hematological parameters as predictor of early onset neonatal sepsis. Int J Contemp Pediatr 2017;4:1-7.

22. Liestiadi DE, Azlin E, Nafianti S. A hematologic scoring system and $\mathrm{C}$ reactive protein compare to blood culture for diagnosing bacterial neonatal sepsis. Pediatr Indones 2017;57:70-5.

23. Ognean MR, Boicean A, Șular FL, Cucerea M. Complete blood count and differential in diagnosis of early onset neonatal sepsis. Revista Română de Medicină de Laborator 2017;1:101-8

24. Kale A, Jaybhaye D, Bonde V. Neonatal Sepsis: An Update. Iranian J Neonatol 2013;4:39-51.

25. Khair R, Sultana T, Roy CK, Rahman MD, Shahidullah M, Ahmed N. Role of hematologic scoring system in early diagnosis of neonatal septicemia. BSMMU J 2010;3:62-7.

26. Makkar M, Gupta C, Pathak R, Garg S, Mahajan NC. Performance evaluation of hematologic scoring system in early diagnosis of neonatal sepsis. J Clin Neonatol 2013;2:25-9. 